\title{
What Will Election Be Without the Media?: An Appraisal of the Media and 2015 Presidential Elections in Nigeria
}

\author{
Bamidele Seteolu \\ Lagos State University, Ojo, Lagos, Nigeria
}

\begin{abstract}
The media role in the political space cannot be exaggerated. The impact of media on politics and political space are awesome; and the media often define agenda for public debates. The growth trajectory from traditional to social media signposts increased relevance and influence of the media in the political space. This work examines the role of media in the 2015 General Elections in Nigeria. The media are assessed against the backdrops of the reportage on party financing, political violence, election handling by the electoral umpire and political campaign. This article is predicated on specific media theories to explain and interpret the strength, significance and reach of the media. There has been a shift in media role of informing the public to influence political behavior and determine the critical issues for public conversations and debates. The paper found that the social media has assumed considerable penetration in Nigeria; and constitute important platforms for intriguing political exchanges including hate campaigns between the major parties. The social media space enables the electorate to directly engage the Presidential candidates on major national issues. The role of social media would likely grow deeper at the 2019 General Elections to deepen political culture, quality of campaign and extent of electoral competition. A fraction of the traditional media, however, assumed partisanship in the coverage of political parties and their interpretations of political news.
\end{abstract}

Keywords: media reportage, political campaign, political culture, political violence, social media, traditional media

\section{Introduction}

The media and election are fundamental concepts that are critical to the sustenance and survival of the democratic process. The media is the fourth estate of the realm; the watchdog and agenda setter in the political system and election is the lubricant through which democratic processes strive. This perception on election was corroborated in an editorial titled, "Strengthening the Electoral Process" thus, "the representative democracy is solidified by credible elections and that it is a formal decision by which a population chooses it leaders" (The Punch Newspaper, 15 April 2015: 22). Put differently, to build a strong democracy, the electoral process must be free, fair and credible to all stakeholders; and the media is at the center of it all.

The media in contemporary times include the traditional media or mainstream media and the new media, which is powered by the Internet and information communication technology. The new media include campaign websites, blogging sites, Internet fundraising tools and social networking sites: Facebook, Twitter, and YouTube (Aronson, 2011). The new media have accentuated democracy and the electoral process globally through increased political awareness and right to free speech (Aronson, 2011). The application of the

Bamidele Seteolu, Ph.D., Senior Lecturer, Department of Political Science, Lagos State University. 
traditional media and the new media are overlapping and mutually beneficial in relation to the electoral process. In this respect, the mainstream and new media are inseparable and networked into each other. Beckett and Mansell (2008) avers that Internet users that are less than thirty years primarily read newspapers online thereby making the newspaper a critical mass medium for the electorate. Boczkowski (2005 cited in Castells, 2009, p. 65) posits that newsrooms in the newspaper, television and radio industries have been transformed through the digitalization of news.

The vibrant Nigerian media space includes some two hundred radio stations, one hundred and fifty television channels and approximately four hundred mostly private print media outlets. The radio is the dominant news platform in the country, closely followed by word of mouth, the television, and the Internet is accessed by over a third of the population (EU Report, 2015). The media in an electoral process mobilizes the electorate to attend rallies and vote, informs the populace on ruling political parties and their programs, investigates ruling party or government, places state officials on their toes to be transparent and accountable to the people, ensure that the political class and their parties play by the rules, ensures that the voters are educated in conjunction with the electoral management body; and more importantly the new media allows for what is called citizens journalism, a new form of journalism that have incorporated the unprofessional journalists and/or citizens into the mainstream journalism (Olukotun, 2003; Iredia, 2001). To Olukotun (2015), the role of the media in providing accurate information, objective reporting and analysis in a season of election cannot be over-emphasized. He observes the media are crucial to the dissemination of credible information and offers a communication level playing field to the principal competitors and the electoral umpire.

To emphasize the significance of media role in electoral matters, Olukotun (2015) recalls the Netherlands experience in 2002 when he said "the power of the media to upset things came to the fore". He posits that the media reflection of the acrimonious exchange among the major political parties cannot be divorced from the crisis following which "a right wing political leader was gunned down a few days before voting day”. This singular incident brought to its wake economic consequences such that several investors withdrew temporarily from the usually tranquil country. Similarly, the crisis that accompanied the gubernatorial elections in the Second Republic in the old Oyo state between Chief Omololu Olunloyo of the opposition party, National Party of Nigeria (NPN); and Chief Bola Ige of the ruling Unity Party of Nigeria (UPN) became accentuated in the media. The opposition party, (NPN), had been declared the winner by the electoral body, but the ruling party candidate, Chief Bola Ige in a state-wide television broadcast critiqued the elections and highlighted the discrepancies in the official results. He challenged the people to resist the attempt of the NPN to assume the reins of power in the state. Following the broadcast, violence erupted in most parts of the state and this re-ignited age-old conflict (Oyeniyi, 2012, pp. 36-37).

The 2015 Presidential elections were keenly contested between the incumbent President Goodluck Ebele Jonathan of the Peoples Democratic Party (PDP) and former military ruler, Major General Muhammadu Buhari of the newly merged opposition party, All Progressive Congress, APC, (The Guardian, 27 April, 2015:16). The media coverage was very high and intense as shown by the mainstream media and the new media respectively. The political parties, party members and supporters, candidates, and the electorate appropriated the media space to inform, solicit support for their preferred candidates, raise funds, kick start rallies and register their grievances, and malign opponents. The Independent National Electoral Commission (INEC) was not left out of this frenzy as it resorted to the traditional and the new media to educate the electorate on the card reader; and the exchange of temporary voter card with the permanent voter card. The political campaign was tainted with 
sectarian, ethnic and religious based pronouncements that accentuated the fragmented nature of the Nigerian state, and sometimes led to violent conflict that raised questions on the structure and premise of the Nigerian federation.

This article interrogates the role of the media in the 2015 presidential elections. It poses questions on the role of the media in the coverage of campaigns of the political parties, setting agenda for issued based campaigns, reportage of pre and post election violence and the education of political parties, candidates, voters, analysts and observers on the relevance and usage of the card reader.

\section{Theoretical Frameworks}

There are plethoras of media theories on political communication including the agenda setting theory in the last five decades. The agenda setting theory was made popular by Bernard Cohen in 1963 when he said the press "may not be successful much of the time in telling people what to think, but it is successful in telling it readers what to think about". The original work is, however, credited to Maxwell McCombs and Donald Shaw in 1972 in their article titled: The Agenda Setting Function of the Media. To McCombs and Shaw, the agenda setting is the process whereby the news media lead the public in assigning relative importance to various public issues. The media accomplish this agenda setting function not by directly telling the public that one issue is more important than the other, which has proven to be ineffective, instead, the media signal the importance of certain issues by giving these issues preferential treatment, such as more frequent coverage and more prominent positions. Castells (2007, p. 4) re-inforced this perspective when he argued that what does not exist in the media does not exist in the public mind even if it could have a fragmented presence in individual minds.

There is evidence that the media have a strong influence on the people's perception of which issues are important and which problems they want their government to do something about. The influence of mass media increases when the need for orientation among the viewers is much. The agenda setting theory explains the effect of media power in shaping the perception of people concerning a particular issue. The agenda setting effect is stronger for concrete issues that are easy to visualize than for abstract issues (McCombs \& Reynolds, 2002; Yagede \& Dozier, 1990; Yangar, Peters, \& Kinder, 1982). The agenda setting hypothesis does not insist the media are trying to persuade the political sphere, it does not change this space with the adoption of prescriptive or advocacy role in the society (political sphere), but rather it is the principal result of the day-to-day work of the press in informing its audiences of opportunities and warning of the dangers real or imagined in their environments and in the rest of the world (Zhu \& Blood, 1997).

To Zhu and Blood (1997) the agenda-setting hypothesis involves two concepts (media agenda and public agenda). The media agenda refers to a list of issues or events that receive news coverage including long term problem or series of events that involves continual coverage such as electoral campaigns of political parties, the budget issue between the National Assembly and the Presidency (in the Buhari civilian administration), and Dasuki gate (a coinage for the diversion of finances meant for arms purchase). This perspective was re-stated by Noelle-Neumann (1979) through a term known as "cumulation”. It is a media trait in the continuing treatment in the press of a topic, trend or theme; and because of the repeated publicity given by the media; the favored topics tend to dominate the attention of the audience. To Noelle-Neumann (1979), repetition helps decrease the noise associated with a particular news item and assists in rhetorical diverse of propaganda. Noelle-Neumann (1979) avers that agenda-setting occurs usually as cumulative effects. It is cumulative in the 
sense that at any specific time a person's ordering of what are important public events or issues resembles the media's estimates of the same public matters; and the media's agenda are measured over an extended period.

Public Agenda refers to the lists of issues that are on the mind of the public. This is usually gauged by a survey of peoples' responses to a set of open-ended questions. The media, by describing and detailing what is out there, present people with a list of what to think about and talk about. This was evidence in the build up to the 2015 Presidential Elections in Nigeria as the media was replete with the assassination of opponents' character and ethno-religious sentiments. The agenda setting function of the media is beneficial for the individual and society as it fulfill a need of the citizens for orientation within the ever expanding and increasingly confusing environment.

\section{Media and Political Campaigns}

Political campaigns provide the platform for political aspirants to solicit the support of voters in their constituencies for executive and parliamentary seats. Political campaigns have always seized upon new modes of communication to reach voters (Oboh, 2015). In an election period, the political parties and candidates seek for platforms to reach large number of audience to articulate their candidacies and manifestoes to prospective voters. The earliest forms of campaigns were characterized by face-to-face communication among party members and voters, and mass events and rallies organized by the parties were dominant. In the "modern" era of political campaigns, communication has shifted to more impersonal channel of the mass media, especially television. This was pioneered in the 1960 American presidential elections by President John F. Kennedy. Since the 1960 episode, the political class embraced the media for campaigns and these have been supportive of their political pursuits (Aronson, 2011).

In the build up to the 2015 presidential elections held on the 28th of March 2015, the parties in a bid to sell their candidates and party programs adopted different media platforms that include pasting of posters, erecting billboards in strategic locations nationwide, placing adverts on the front pages of major national dailies, political advert placements on television channels, playing jingles on radio and launching Internet presence through Websites, Blogs, Facebook, Twitter, YouTube accounts, BlackBerry Messenger and WhatsApp. These media channels were deployed to increase electoral chances in the keenly contested campaigns (The Punch, January 17, 2015: 13).

The launch of former President Goodluck Jonathan's campaign on social media in the 2011 general elections attracted in excess of 246,000 Facebook fans in a few weeks, and each of his post attracted in excess of 6,000 responses (CNN, 2010). He had attracted 500,000 Facebook fans in March, 2011, and the figures increased to 1,761,812 followers in January 21, 2015. President Goodluck Jonathan had 9,134 followers on his Twitter handle (@GEjonathan) while his closest opponent Gen. Muhammadu Buhari attracted 12,500 followers in less than six hours into the launch of his Twitter account. The figure increased to 17,500 when the Sahara Reporter captured the news (December 22, 2014). As the election drew near Buhari had 518,000 followers on his handle (@Mbuhari) while his friends on Facebook were 165,776. The new media has attracted the support of technologically savvy youth to support the candidates as shown in the figures mentioned earlier.

The application of the new media by the political class has occasioned speed and fluidity in information flow thereby bypassing the gate keeping function of the traditional media (Castells, 2007). The mainstream media still had important role in the 2015 Nigerian presidential elections since it had to adopt the new media for its interactions with the media audience. To Castells (2007), this synergy reflects the vertical and horizontal 
communication modes. The media channels such as the Channels TV, Television Continental, African Independence Television, Silverbird Television, National Television Authority (NTA) and the newsprint media outlets like The Nation, The Punch Newspaper, The Vanguard Newspaper, This Day, The Tribune, had interactive features on YouTube, Facebook, WhatsApp and Twitter.

It is imperative to explain the three broad dimensions of the role of the media in the 2015 presidential elections campaign. First, the influencing role the candidates were having on the media or the agenda setting role of the media on issue base campaigns. Second, the use of media techniques to "murder" opponents' character; and the third involved media campaign by political parties and candidates based on sectarian premise for votes. The mainstream media and the new media were utilized for these purposes.

In the 2015 presidential elections, the media was used to project the candidates to the audience or electorates before the election proper. As pointed out by Castells, (2007, pp. 3-4), political actors exercise considerable influence over the media. In other words, the political class raised issues for the media during election campaigns, which the media projected to the audience. Since the political actors are perceived as the opinion builders, it became imperative for the media to cultivate cordial relations. This was evidenced in the media presence at the candidate and rallies, press conferences. Moreover, the utterance of the former first lady, Mrs. Patience Jonathan at a campaign rally in Calabar, Cross Rivers state that "President Buhari was old and when people become old, may not reason well and their brain may even be dead" elicited intense responses and controversies in the media (The Punch, March 5, 2015).

The media control political agenda and decide the party that wins or loses election. This perspective was buttressed by Budge and Farlie (1983) when they averred that political parties actively attempt to influence the salient issues that are favorable to their interests. The basic assumption is that there are latent dimensions that can be brought to the surface by the parties and the media during an election campaign (Narud, 1996, pp. 46-48). Underlying the salience theory is the idea of issue-ownership in the sense that voters associate an issue with a specific party, believing that the party may have a better policy or may be more competent to handle a particular problem than other parties (Petroci, 1996). Issue-ownership thus provides the link between issue-voting and the agenda-setting role of the mass media. The interface of issue-voting and the agenda setting role of the mass media have been characterized by corruption and how to curb it.

The media portrayed former President Jonathan as weak and unsupportive of the war against corruption through his popular mantra "Stealing is not Corruption" while Buhari’s antecedents were projected as demonstrating the political will to fight corruption (The Punch, January 12, 2015: 21, February 26, 2015: 64). To Pat Itomi, a former Presidential aspirant:

I do agree with Soludo that issues matter. I also think that those who turn to divisive emotion-laden type casting of others rather than issues pertaining to the well-being of the Nigerian people do a grave disservice not only to democracy but to the long term common good of all. (The Punch, February 5, 2015: 26)

Put differently, the campaigns lacked substance in terms of debating of issues ranging from the country's external reserves which is declining, the electricity and energy sector, the large scale unemployment in the country. It had focused on rather mundane issues such as the expected role of the entertainment industry and actors in the economy (The Punch, March 11, 2015: 8).

The use of media assassination techniques to "murder" opponents' character characterized the 2015 presidential elections. To Castells (2007), the character attack and mudslinging of opponents is a ploy by 
political parties to malign or destroy the credibility and character of rivals for electoral advantage. This is actualized through the manipulation and fabrication of half truth and lies. Instances are the twin documentaries on the Nigerian Television Authority (NTA) and African Independence Television (AIT) about "The Real Buhari" and "The Lion of Bourdillon". These documentaries elicited controversies in the mainstream media and the new media especially on YouTube where it had thousands of views (Channels YouTube and Television Continental YouTube). The controversies reflect in the article titled, What do Nigerians do with the Tinubu documentary? The writer reasoned that the documentary was meant to destroy the image of Senator Bola Tinubu before the electorate (The Punch, March 5, 2015: 64).

Similarly, the death wish advert that was sponsored by Governor Ayo Fayose of Ekiti State on the front page of The Punch (January 19, 2015) captioned, “NIGERIANS BE WARNED!” Fayose insinuated in the advertorial that Nigerians may risk another state burial if they cast their votes for the septuagenarian, Alhaji Muhammed Buhari. The Peoples Democratic Party (PDP) and the President's Campaign Organization's denial of the advertorial did not deter its sponsor, Mr. Fayose who owed no apology. Despite the outcry that followed the controversial advertorial, he placed a fresh advert wherein he wrote that if former President Olusegun Obasanjo in 1999 was called "Baba” (father) at 62, Buhari should be called "Baba baba” (grandfather) at 72 in 2015 (The Punch, January 22, 2015). He insisted that President Buhari was too old to govern Nigeria, and he insisted his candidacy was an agendum of a few cabals (The Punch, January 24, 2015).

The third aspect of party campaigns adopted in the presidential elections was based on sectarianism, political and social cleavages to mobilize the electorates to vote in specific manners. Cleavages reflect differences in the electorates' attitude to a politically relevant issue. These cleavages could be channeled through the media to activate ethno-religious sentiments. The 2015 Presidential Election Campaigns were based on ethnic and religious fault lines as former President Goodluck Jonathan attended different denominational church services to seek for the votes of Christian segment of the society while his deputy; Alhaji Namadi Sambo met with the Muslims north to canvass for votes. The Vice President posted a video on YouTube that suggested the All Progressive Congress presidential candidate Alhaji Muhammadu Buhari (rtd) was encircled by Christians while key stakeholders of the PDP except for President Goodluck Jonathan were Muslims. He urged the party supporters at the Minna rally to dismiss anybody who argued that APC was more Muslim-friendly than PDP. The former Vice President claimed his party had advantage if religion was the yardstick to elect candidates in the 2015 General Elections. In his words, “our Chairman, Adamu Mu'azu, is a Muslim; the Director General of the Campaign Organisation, Adamu Ali is also a Muslim. I am a Muslim. It is only our presidential candidate that is a Christian”. He listed at a rally in Jigawa, Jigawa state; the key northern Muslim ministers in the Jonathan administration to underscore his assertion that the PDP was a better option for Muslims in the North. At a campaign event in Zamfara state, former Vice President Sambo jokingly introduced himself as Muhammadu of Madina, and claimed direct link with Madina (The Punch, February 5, 2015: 14).

The PDP issued a statement through its national working committee that the defeat of the party at the 2015 Presidential elections was based on hate speeches by the opposition led by Buhari (The Punch, May 5, 2015: 1). In a similar statement issued by the former APC National Publicity Secretary, Alhaji Lai Mohammed, the former President, Dr. Jonathan exploited the "pulpit to make political and policy statements and making a show of what should ordinarily be very personal religious affairs". He averred that his church outings induced ethno-religious division among Nigerians (The Punch, January 9, 2015: 9). This article notes, however, that the APC choice of the Vice Presidential candidate, Prof. Yemi Osibajo was predicated on religion in order to avoid 
a Muslim-Muslim ticket thereby responding to religious sensibility of the electorate (Vanguard, December 18, 2014).

\section{Media and Financing of Parties}

Funding plays an essential role in politics, and the high cost of election campaigning means that politics often does not afford equal opportunities for all to compete (Ballington \& Kohane, 2014). One of the reasons why the cost of running campaigns in Nigeria is the very high is the "mobilization money" being given to the electorates for mobilization to the campaign venue. This assertion is supported by media report that the Peoples’ Democratic Party and the major opposition party, All Progressive Congress induced the electorates with amounts ranging from five hundred naira to five thousand naira depending on the distance of their location to the campaign venues (The Punch, February 1, 2015: 8). Another leg of this "mobilization money" is the campaign funds that are allocated to campaigns coordinators, ministers, special advisers, closed aides and friends, support groups and traditional rulers to the tune of over two trillion naira to mobilize their controlled area to vote for the PDP (The Punch, April 19, 2015: 2). A third reason why electoral campaigns are expensive in Nigeria is payment of nomination fees, which was twenty million naira for Peoples Democratic Party and twenty-seven million naira for All Progressive Party presidential aspirant respectively (This Day, November 5, 2014: 56). The fourth reason is the expensive nature of media politics, which include advertising, pollsters, phone banks, consultants, etc. (Castells, 2007). With all of these, the financial costs of canvassing for a party's candidates and proposed policies to the electorate will not likely be incurred solely by the candidates (Surstein, 1997 cited in Hopkins, 2004).

Consequently, those who have financial means, moneyed networks, patrons and party support are disproportionately advantaged over those who do not, making the former more likely to compete for and win political office. Globally, the cost of election and the source of finance for running election campaigns have been through close scrutiny because a completely unregulated system of funding allows economic inequalities that may well be accepted as the norm to be translated directly in political inequalities, which generally are not (Surstein, 1997 cited in Hopkins, 2004: 16).

The Peoples Democratic Party and the All Progressives Congress sourced campaign funds from: party members, wealthy business persons, state-owned corporations, foreign donors, the use of modern technological tools to garner public donations and some illegal means such as siphoning of state fund to finance election campaigns. The foregoing instances of campaign financing will be further discussed within the rubrics of three theoretical models of party financing for election campaigns. These are the mass party model, clientilist mass party financing model and the externally-financed elite party model (Surstein, 1997 cited in Hopkins, 2004).

\section{The Mass Party Model}

The Mass Party model of party financing (Duverger, 1954) was adopted by the All Progressives Congress and the Peoples Democratic Party as aspect of their financing platforms for the presidential elections. The All Progressives Congress got a million naira donation from a 95 year old woman, Hajiya Fati Koko to sponsor Buhari's campaign (Premium Times, March 21, 2016) and a nine year old donated ten thousand naira from her savings to Buhari's campaign (Channels Television YouTube, 2015). While in a fund raising dinner, the PDP members, PDP Governors and friends of PDP donated more than N21 billion to campaign fund of President Goodluck Jonathan (This Day, 2014) 


\section{The Clientelist Mass Party Financing Model}

This was adopted in the run up to the March 28, 2015 presidential elections when citizens became party workers for the prospects of favors from elected party candidates. This favor varies from the award of lucrative government contracts, appointment into cabinet positions, and employments of relations and cronies in the state controlled establishments. The principal officers of Buhari-Osibajo campaign organizations such as its former Director General, Mr. Rotimi Amaechi became the Minister of Transport in the Buhari administration. The appointments suggest that the serving Minister of Transport had probably been a major contributor to the campaign fund of the APC.

\section{The Externally Financed Elite Party Model}

Technological change has brought attractive alternatives to the labor intensive mass party model by using capital intensive campaign techniques, based on extensive use of audio-visual media, direct mail and information technology. The parties are increasingly able to reach mass electorates with relatively few, albeit often professionalized party workers. The All Progressive Congress created five platforms to receive short messages, distribute "APCGMBPYO” ringtone online, receive payments to some bank accounts online through mobile phones and laptops, and sell scratch cards (The Punch, January 24, 2015: 12).

\section{INEC and Its Usage of Media}

Traditionally, INEC have largely relied on one-sided communication approaches such as the television, radio or print medium to disseminate information. Since the advent of new media such as Facebook, Twitter, blogging sites and You-tube, the means of information dissemination became two way process. In other words, the audiences have the opportunity to directly ask questions, response to issues, address and clarify rumors (IFES, 2015). INEC later adopted a deliberate approach to social media use through a Twitter account with over 160,000 followers to educate and inform the electorate about procedures for voting (The Punch, January 17, 2015: 13). Following a 2011 general elections that were characterized by rumors and the frequent misinformation in the media, INEC implemented a number of measures during the 2015 general elections designed to increase its ability to proactively respond to issues, and address queries from citizens as these arose.

The Independent National Electoral Commission (INEC) opened a Citizens' Contact Centre (ICCC)—a facility allowing the general public constant access to the Commission with enquiries and exchange of information between 9am to 5pm. It later offered round-the-clock service to the general public. The centre could be accessed through telephone lines, Facebook, Twitter, and INEC website (News24, 2013). In addition to creating Election Operations Center, former INEC Chairman, Prof. Attahiru Jega, assigned dedicated staff to monitor INEC social media channels, which grew exponentially in number of fans and followers as the electoral period progressed. These channels provided additional means for INEC to respond to citizen concerns relating to new voting procedures for the 2015 general elections, including a national exercise to distribute over fifty million PVCs to registered voters, and the implementation of technology-based card reader (IFES, 2015).

INEC introduced an innovative web and SMS-based facilities, which would enable voters to ascertain whether they are on the register of voters, their points of registration, and the collecting points for PVCs at the wards (Nigerian Tribune, February 6:21). Due to the public enlightenment, sensitization and voter education on the multiple media channels and outlets like the radio, television, newspapers, and the new media platforms a total of $45,098,876$ PVCs were collected by voters thus constituting $65.81 \%$ as at February 16, 2015, but the 
total number of valid votes in the 2015 general elections were 28,288,083 or 41.096\% (The Nation, April 1, 2015:1).

INEC enlightened the citizens on the enormous benefits of the card reader, which once configured can only read PVCs issued by INEC and authenticates the identity of the voter by matching his/her fingerprints with that stored on the chip. The card reader keeps a tally of cards read with the details sent to a central server using an SMS. The stored information on the server would enable INEC audit results from polling units, as well as do a range of statistical analyses of the demographics of voting, and lastly, the RA/Ward Collation Officer can use this information to audit Polling Unit result sheets and ascertain the validity of accreditation figures (The Nigerian Tribune, February 16, 2015:21). To give confidence to the critical partners on the efficacy and efficiency of the card reader, it was tested by INEC in twelve states of the geo-political zones, and this was judged to be successful as it met the objectives it was created for (The Punch, March 11, 2015).

\section{Media Coverage of Political Violence}

The media effect theory provides a framework to interrogate the role of the mass media in influencing and intensifying socio-political conflicts and violence, such as electoral violence. The media can contribute to intensification of such conflicts by reporting the occurrence and location of such violent conflict, publicizing the causes of such violence or giving prior publicity to the likely occurrence of such conflicts. McQuail (2000) recognizes that the media can instigate collective behavior during situations of public turmoil, such as rioting. Ownership and economic influences also tend to affect the action of the media during electoral conflicts and violence. Historically, in Nigeria, the media has been playing very crucial role in election processes and in crises that accompany elections since the colonial period. The mass media performance in the 1965 and 1983 general elections in Nigeria that witnessed massive violence and subsequently led to the collapse of the First and Second Republics has been at the fore of academic discourse.

Nigeria's electoral processes are often riddled with fraud and violence orchestrated by politicians who regard politics as zero-sum game (Ikpe, 2004). To Ologbenla, electoral violence as an aspect of political violence may include all sorts of riots, demonstrations, party clashes, political assassinations, looting, arson, thuggery, maiming, kidnapping, and ballot snatching which occurs before, during, and after elections. He went further to assert that the foregoing scenarios could be regarded as electoral-motivated crises employed to alter, change or influence by force or coercion the electoral behavior of voters or voting pattern or possibly reverse the electoral decision in favor of a particular individual, group or political party (The Nation, January 14, 2015).

The bitter political competition between the North and South in the buildup to the 2015 presidential elections heightened political tension. Beside, the APC campaign train started its rally in Port Harcourt, Rivers State; and supporters who were on their way to the campaign venue were beaten, maimed and inflicted with wounds (The Nation, January 14, 2015). Due to the incident that occurred in Rivers State and was publicized in the media, there were reprisal attacks on two campaign buses of former President Goodluck Jonathan by some youths at the Mangu Street Junction in the Jos North Local Government Area of Plateau State (The Punch, January 12, 2015).

This article discusses some of the factors that trigger violence before, during, and after elections. First, the inflammatory remarks by political actors that are been reported as news in the media; Threats and counter threats have been issued by the northern and southern political leaders about the elections. A prominent Northern leader, Lawal Kaita was quoted to have said that "the only way Nigeria can remain as one is for the 
Presidency to return to the North this 2015” (The Vanguard, 2015:3). A notable ex-militant in the Niger Delta region, Tompolo, however, declared on 29 January, 2015 that “... I remain resolute on my earlier position that President Jonathan 'must' win this election for Nigeria to continue to stay together” (The Nation, 2015: 1). Another ex-militant, Mujahid Asari Dokubo, leader of the Niger Delta Peoples' Volunteer Force (NDPVF), stated that "there will be no peace in the whole country if Goodluck Jonathan is not President by this 2015" (Premium Times, 2013). He reiterated his threat of violence in another statement when he was reported that oil exploration and mining will be made difficult, if power shifts to the North (The Nation, January 14, 2015: 17). The All Progressive Congress (APC) National Chairman, John Odigie Oyegun was also quoted to have said, "... as a party, we wish to reiterate that we will not hesitate to consider forming a parallel government if this 2015 elections are rigged either by the use of security agencies (police and military), to harass, intimidate and cajole voters or through the compromised Independent National Electoral Commission” (This Day, 2015: 2).

Second, internal Party wrangling could threaten the transition process. The ruling and the opposition parties are enmeshed in internal party crises. The APC consists of strange ideological bedfellows who are pre-occupied with divergent interests. The APC ascribes to progressive leaning as reflected in the merger of the parties that claim progressivism; Action Congress of Nigeria (ACN) All Nigeria Peoples Party (ANPP), and the Congress for Progressive Change (CPC). The crisis in the former ruling party, PDP, led to the cross carpeting of conservatives into the APC before the 2015 general elections. Subsequently, the APC became characterized with competing ideological persuasions: progressives, conservatives, and reactionaries. More importantly, the groups within the APC struggle to control the machinery of the party and occupy critical positions in the Buhari and Osibanjo campaign outfit. The differences in the PDP before 2015 general elections were sharp leading to the exit of gladiators of the party including former governors to the APC. The division in PDP over heated the polity, undermined democratic stability; and raised the stakes of the 2015 general elections.

Third is the politics of bitterness, intolerance and desperation, which predisposes the political class to electoral malfeasance. The political class beat the drum of war and their followers respond positively to the campaign of discord thereby raising the fear of violence and electoral crisis gradually in the sub-consciousness of the electorate as they go about their political campaigns (The Nation, 14 January 2015: 17). To Ologbenla, "in Nigeria, the purpose of such violence, apart from seeking redress through illegal means, including killing, maiming, destruction of property, is also 'to destroy it' if we cannot have it” (The Nation, 2015: 17).

\section{Conclusion}

The media reported that despite the cases of infraction of the electoral law such as electoral violence, hate media campaign, violation of section 91 (2) of the Electoral Act (2010) as amended with respect to the financial limits for the general elections, the international observers from the Economic Community of West African States (ECOWAS) Election Observer Mission headed by former president of Ghana, John Kuffour, Head of the African Union Election Mission, former president of Liberia, Dr. Amos Sawyer, Chief Observer of European Union Election Observer Mission (EUEOM), Mr. Santiago Fisas Ayxela offered pass mark to INEC for organizing and conducting free, fair and credible elections. It equally reported that the missions observed cases of violence in some locations, delay in the arrival of INEC officials and voting materials, malfunctioning of card readers, ballot snatching, and Boko Haram insurgents attacks (This Day, March 30, 2015: 12, March 31, 2015: 31).

More significantly, the missions noted that some media outlets were biased in the reportage of 2015 general elections. The Europe Union report indicted the Nigeria Television Authority (NTA), African 
Independent Television (AIT), Federal Radio Corporation of Nigeria (FRCN), and Ray Power's coverage of the elections, which were skewed in favor of the incumbent Peoples' Democratic Party (PDP) and President Goodluck Jonathan. These media outfits provided least coverage in the news programs and non-news editorial programs to the opposition All Progressives Congress APC and its Presidential candidate Muhammadu Buhari. In contrast, Channels TV demonstrated "generally balanced reporting of key political contestants and the three newspapers monitored offered relatively balanced and diverse coverage, based on the EU Report 2015”.

The indictment of some media outlets by foreign observers should be understood in terms of the structure of ownership in Nigeria. The state and privately owned media organizations are vulnerable to the manipulations of the owners. The state owned and funded media organizations have shown biases and leaning to specific parties in the coverage of parties and politics. The privately owned media are sometimes established to ventilate the political interests of the owner and his allies. The logic of ownership defines the editorial slant, news content and emphases of some of the media houses. The bias nature of media reporting has been a major impediment to the democratic process especially as these relates to creating misperceptions on candidates, parties or processes, and raising political tension. The misperceptions are deliberately constructed as "sacred" with a view to influence the political behavior of the electorate or falsely set agenda on a specific issue. The media regulatory body, the Nigerian Broadcasting Commission should be more pro active to insist on the right ethical conducts and impose penalties for violations.

The new media played tremendous in the 2015 general elections. It electrified the process, increased enthusiasm in the political process, raised the level of voters awareness and consciousness. The new media were extensively used by the parties especially in the 2015 general elections to canvass party positions, project the selling points of their candidates and monitor election results. It elicited the enthusiasm and interest of the youth and middle class in the political process. The article has discussed and provided evidences on the influence and impact of the social media. The new media reach and impact will likely increase in qualitative terms in subsequent elections depending on higher proliferation of smart communication tools, increasing globalization, and the greater desire in the electorate to secure more credible elections.

\section{References}

Aronson, E. D. (2011). Cyber-politics: How new media has revolutionized electoral politics in the United States. Retrieved from http://commons.colgate.edu/car/vol9/iss1/7

Ballington, J., \& Kahane, M. (2014). Women in politics: Financing for gender equality. In Handbook on Funding of Parties and Election Campaigns, Political International, IDEA. Stockholm: Sweden.

Beckett, C., \& Mansell, R. (2008). Crossing boundaries: New media and networked journalism. Communication, Culture and Critique, 1(1), 92-104.

Boczkowski, P. (2005). Digitizing the news: Innovation in online newspapers. In M. Castells (Ed.), Communication Power. New York: Oxford University Press Inc.

Burge, I., \& Farlie, D. (1983). Voting and party competition. London: Wiley.

Castells, M. (2007). Communication, power, and counter-power in the network society. International Journal of Communication, $1,238-266$.

CNN .(2010). Goodluck Jonathan: The Facebook President. Retrieved from http://www.edition.cnn.com/2010/TECH/social.media/10/0 Duverger, M. (1954). Political parties. London: Methuen.

EU Report. (2015). European Union Election Observation Mission Final Report of Federal Republic of Nigeria 2015 General Elections 28 March \& 11 April 2015.

Ikpe, U. B. (2004). Attitudes of politicians to electoral process in Nigeria. Proceedings from the Workshop on Sustainable Democracy, Nigeria. 
Iredia, T. O. (2001). Information dissemination, voters mobilization and election monitoring in Nigerian electoral process. In M. Ogun (Ed.), Improving the Fortunes and Destiny of Nigeria through the Ballot Box. Abuja: Catholic Laity Council of Nigeria.

McCombs, M., \& Reynolds, A. (2002). News influence on our pictures of the world. In J. Bryant, \& D. Zillmann (Eds.), Media effects: Advances in theory and research. Lawrence.

McCombs, M., \& Shaw, L. D. (1972). The agenda-setting function of the media. Public Opinion Quarterly, 36, 176-187.

McQuail, D. (2000). Mass communication theory. London: Sage Publication.

Narud, H. (1996). Voters, parties and governments: Electoral competition, policy distances and government formation in multi-party systems. Oslo: Institute for Social Research.

News24. (2013). INEC opens citizens contact centre. Retrieved from http://www.news24.com.ng/politics/News/INE

Noelle-Neuumann, E. (1984). The spiral of silence: Public opinion-our social skin. Chicago: University of Chicago.

Oboh, G. (2015). Reflecting on the Nigeria media, elections and the African democracy. Retrieved from http://www.aijssnet.com/journals/Vol_4_No_3_June_2015/9.pdf

Olukotun, A. (2003). The transition and the media. Africa Association of Political Science, 5(2), 31- 44.

Olukotun, A. (2015). A two-day workshop on reporting election: A non-partisan approach, media scholars network in collaboration with independent national electoral commission, INEC.

Oyeniyi, A. B. (2012). Radio don’t kill, people do: Media, post election violence, and democracy. Ibadan Journal of Peace and Development, 1, 29-52.

Petroci, J. R. (1996). Issue ownership in presidential elections, with a 1980 case study. American Journal of Political Science, 40, 825-850.

Sunstein, C. (1997). Free markets and social justice. In J. Hopkins (Ed.), The problem with party finance: Theoretical perspectives on the funding of party politics.

Yagede, A., \& Dozier, D. (1990). The media agenda-setting effects of concrete versus abstract issues. Journalism Quarterly, 67, 3-10.

Yangar, S., Peters, M., \& Kinder, D. (1982). Experimental demonstrations of the "Not-so-minimal” consequences of Television programmes. The American Political Science Review, 76, 848-858.

Zhu, J., \& Blood, D. (1997). Media agenda-setting theory: Telling the public what to think about. In B. Kovacic (Ed.), Emerging Theories of Human Communication (pp. 88-114). Alberg NY: State University of New York Press. 